Received 08 January 2021 Accepted 09 February 2021

Link to DOI:

10.25220/WNJ.V05.11.0017

Journal Website: www.worldnutrijournal.org

\title{
The importance of school snacks for primary school-aged children nutritional support as the foundation of Sekolah Generasi Maju in Indonesia
}

\author{
Saptawati Bardosono, ${ }^{1,2}$ Pittara Pansawira, ${ }^{1}$ \\ 1. Indonesian Nutrition Association/Perhimpunan Nutri Indonesia, Jakarta, Indonesia \\ 2. Department of Nutrition, Faculty of Medicine, Universitas Indonesia, Dr. Cipto Mangunkusumo \\ Hospital, Jakarta, Indonesia
}

\begin{abstract}
As a developing country, Indonesia is still burdened with high prevalence of child malnutrition including those in primary school. One of the main factors affecting nutritional status of children is snack consumption in school. School snacks are expected to be able to contribute to nutritional requirements. This narrative review is written to collect information and knowledge regarding nutritional status, nutritional requirements, factors determining nutritional status of primary school children and, lastly, recommended school snacks. This review also acts as a basic information for school snacks program establishment.

Keywords Indonesia, nutritional status, school-aged children, snacks
\end{abstract}

\section{Background}

Primary school age acts as the continuation from toddler to the next phase of children's growth, development, and learning. In this phase, nutrition is one of the most important aspects. Nevertheless, high numbers of malnutrition in school-aged children remains a national problem.

Despite of its economic growth, Indonesia suffers from high prevalence of undernutrition, obesity and micronutrient deficiency in children (commonly known as the triple burden). ${ }^{1}$ According to Basic National Health Research/Riset Kesehatan Dasar (Riskesdas) $2013,{ }^{2}$ as much as $11.2 \%$ of primary school-aged children were underweight, $26.4 \%$ were

\footnotetext{
Corresponding author:

Pittara Pansawira, MD, MGizi

Indonesian Nutrition Association/Perhimpunan Nutri Indonesia,

Wisma Nugraha Building

$5^{\text {th }}$ Floor, Suite 501

Jl. Raden Saleh Raya No.6, Central Jakarta, Indonesia

Email: pittarapansawira@gmail.com
}

anemic and $18.8 \%$ were obese. Prevalence of stunted school-aged children was still high (30.7\%), regardless of its decline from $35.8 \%$ in year 2010 Riskesdas data. Regionally, data from West Java Riskesdas $2018^{3}$ showed $16.43 \%$ of primary schoolaged children were stunted, $6.45 \%$ were severely stunted, $5.16 \%$ were underweight, $1.88 \%$ were severely underweight and $8.9 \%$ were obese. In Bandung, the capital city of West Java, 20.64\% school-aged children were classified as stunted, $6.51 \%$ were severely stunted, $4.54 \%$ were underweight, $0.47 \%$ were severely underweight and $7.95 \%$ were obese. Malnutrition in children may affect physical and mental development. A research regarding a relationship between nutritional status and learning performance in Nairobi, Kenya, Africa, shows that children with low nutritional status or obese demonstrated poor learning performance, poor classroom and out-of-class activity, and low attendance. ${ }^{4}$ In addition, several studies indicate that children with short stature (stunting) suffered from 
impairment in brain and motor development, lower levels of intelligence, and learning difficulties. ${ }^{5-7}$

The reason behind the underweight status in schoolage children is the lack of fulfilment of nutritional requirements. This involves the interaction between the lack of nutrition intakes from food and impaired absorption of nutrients. On the contrary, the cause of overweight in school-aged children is the interaction between the excessive calorie intakes and the lack of physical activity. To overcome this, it is necessary to ensure children have appropriate food intakes according to the recommended dietary allowances/angka kecukupan gizi (AKG) for 7 to 12-year-old children. ${ }^{7}$ Supports from various parties such as local governments, teachers, parents, and school cafeteria managers are crucial to the sustainability of the school's nutritional support program. Programs and facilities that are applicable in accordance with the school conditions are also necessary. School of advanced generation/Sekolah Generasi Maju is a school that will provide facilities for children to gain the best nutritional support as well as knowledge improvement. Through nutritional support programs and facilities in school cafeteria, schoolchildren are expected to gain proper knowledge on nutrition and health, as well as to secure healthy nutritional status that will improve their learning potential at schools. Therefore, this narrative review is compiled as a guideline on various important nutritional requirements of school-age children and food ingredients that can be made into healthy and nutritious snacks sold in the school cafeteria.

\section{Nutritional status of primary school-age children in various cities in Indonesia}

Researches conducted in Indonesia have shown varying numbers on the nutritional status of primary school-aged children. One of them is a study in Tangerang Regency, West Java, where the figure shows that $17.8 \%$ of school-aged children were underweight and very underweight, while $7.3 \%$ of them were overweight. ${ }^{8}$ A study on 50 primary school children in Serang City, Banten, West Java, shows that $3 \%$ of them were very underweight, $6 \%$ were underweight, $13 \%$ were overweight, and $8 \%$ were very overweight. ${ }^{9}$ Another study in a primary school in Surakarta shows that $6.59 \%$ of the schoolchildren were underweight and $21.97 \%$ were overweight. ${ }^{10}$

A Study by Yurni et al. ${ }^{11}$ on a primary school in Bogor city, West Java, concluded that out of $52 \%$ of primary school children, 3.8\% were underweight, $11.5 \%$ were overweight, and $11.5 \%$ were obese. Another study by Sekiyama et al. ${ }^{12}$ on a primary school in a village in West Java shows that out of 68 children, $2.9 \%$ were underweight, while $17.6 \%$ of them were overweight and very overweight. A research conducted in Makassar, the capital city of South Sulawesi, by Syahrul et al. ${ }^{13}$ on 877 primary school children shows that $14.5 \%$ of them were overweight and $20.4 \%$ were underweight. Jahri et al. ${ }^{14}$ conducted a research on 350 primary school children in Bengkalis Region, Riau, Sumatra and found $1.7 \%$ of the children were very underweight, $12 \%$ were underweight, $5.7 \%$ were overweight, and $4.6 \%$ were obese.

What about Bandung city? A cross-sectional study by Yulia et al. ${ }^{15}$ on 7 public schools in Bandung shows that $21.7 \%$ of the children were overweight and $19.7 \%$ were very overweight. Another study by Riana et al ${ }^{16}$ in a primary school in Bandung shows that out of 145 schoolgirls, 2.1\% of them were very underweight, $6.9 \%$ were underweight, while $11.7 \%$ were overweight, and $4.8 \%$ were very overweight.

Unfortunately, there have not been many studies that uncover the problem of micronutrient deficiency in primary school-age children. A study by Bardosono et $\mathrm{al}^{17}$ on 245 primary school-age children with underweight status in Jakarta and Surakarta shows that about $12 \%$ of the children had iron and zinc deficiencies. Southeast Asian Nutrition Survey $\left(\right.$ SEANUT) ${ }^{18}$ research in 48 cities in Indonesia on children aged $0-12$ years shows that $55 \%$ of the children were anemic, $4.1-8.8 \%$ of children suffered from iron deficiency, and 25.2$39.2 \%$ of children were stunted. This condition indicates that school-age children are not different from toddlers, who experience the triple burden of malnutrition, with undernutrition, overnutrition, and micronutrient deficiency. 
The energy and nutritional requirements of Indonesian primary school-aged children

In the primary school-age period ( $7-12$ years), children's physical growth occurs gradually and continuously. However, their cognitive, emotional, and social development happen very rapidly. Appropriate nutritional intakes are essential for the children to achieve optimal growth, development, and health, as well as to prepare themselves for changes in the body during adolescence. ${ }^{19}$

Nutrients particularly required by primary school-aged children are carbohydrates, proteins, fats, vitamins, iron, zinc and iodine. Carbohydrates are important sources of energy for the body and brain. Proteins are necessary for cell growth and brain development. Fat is a source of energy that helps with the absorption of vitamin A, D, E and K, and brain development, as well as provides good taste in food. Unsaturated fats, which are omega 3 and 6 fatty acids, help with brain development, learning concentration, allergy prevention, as antiinflammatories, and brain cells protection. Vitamins, especially vitamin A and C, help to maintain immunity. Vitamin D helps with calcium absorption, which is important for bone and teeth growth. Vitamin D also plays as an antiinflammatory and improves immunity. Minerals, such as calcium, iron, zinc and iodine, are important for bone, muscle, dental, and cell growth, anemia prevention, as well as brain development. Fibers help to maintain gastrointestinal health and help to facilitate bowel movements. ${ }^{19-21}$ Energy and nutritional requirements for primary school children must correspond with Indonesian AKG, as stated in Table 1.

Regarding special nutrients to support school-age children's physical growth and cognitive development, research by Bardosono et al. ${ }^{17}$ on 245 primary school-age children shows that milk supplementation fortified with iron and zinc for 6 months has improved the scores of fast thinking compared to the control group. A systematic study by Falkingham et $\mathrm{al}^{22}$ shows that iron supplementation improved children's attention and learning concentration, as well as improved the intelligence quotient (IQ) in school-age children with anemia.
Food that contain both nutrients are listed in Table 2. Those special nutrients can be obtained from basic food ingredients or fortified food (e.g. milk or flour).

\section{Factors determining primary school children's nutritional status}

The nutritional status of school-age children is affected by several factors, such as adequate nutritional intake, parents' level of education, breakfast habits, and homemade meals they bring to school. According to Riskesdas 2010, ${ }^{23} 44.4 \%$ of primary school-age children consumed food with inadequate energy. About $30.6 \%$ of them had protein intake below minimal requirement. There is no national data available on excessive consumption of energy and protein on school-age children.

Study by Syahrul et al. ${ }^{13}$ conducted in Makassar, found that there was a significant correlation between mothers' level of education to undernutrition status (underweight) in school children. Meanwhile, mothers with a high level of education were significantly correlated to overnutrition status (overweight). This suggests that a highly educated mother tends to prevent undernourishment while simultaneously increases their children's risk of having overnutrition since every mother plays a vital role in their child's dietary intake. Wolde et al. ${ }^{24}$ indicated that parents with lower level of education tend to have children with undernutrition due to the lack of a healthy lifestyle, including the absence of healthy breakfast with balanced nutrition. Therefore, addressing the level of education alone is not sufficient to overcome nutritional problems. It must be accompanied by an improvement in health and nutrition knowledge.

Concerning breakfast, research by Anzarkusuma et al. ${ }^{8}$ indicates that $94.4 \%$ of the children stated that they always have breakfast before going to school. Similarly, a study by Nuryani et al. ${ }^{25}$ shows that $64.9 \%$ of the children always eat breakfast before school. Breakfast supposedly contributes $20-30 \%$ of total calorie requirement for a day, or about $300-600$ $\mathrm{kcal}$, which in balanced nutrition composition consists of $50-65 \%$ carbohydrate, $15-20 \%$ protein, and $<30 \%$ fat. ${ }^{20}$ In general, schoolchildren consume rice, bread, instant noodles, or fried rice as breakfast,${ }^{26}$ of which appear to be lacking in protein, 
fiber, iron and vitamins. An example of breakfast menu that fulfills school children's nutritional needs is a portion of fried/uduk/turmeric/white rice, with egg side dish, slices of tomato, carrot, and cucumber, and a glass of milk or fruit juice; or 2 pieces of bread filled with omelette and a slice of cheese, tomato, and cucumber.

To help fulfilling daily nutritional requirements, lunch box meals or snacks sold in school should contribute about $10 \%$ of total calorie needs in a day, or about 160-200 kcal. However, research by Anzarkusuma et al. ${ }^{8}$ indicates that $79 \%$ of school children do not have the habit of bringing their own meals from home. This is similar to a study of school children Serang City that shows only $25 \%$ of the children have the habit of bringing homemade meals and only $54 \%$ are accustomed to bring their own drink to school. This study also revealed that the common content of their lunch boxes are rice, a side dish, and water. While the 5 preferred types of snacks to buy in school are bread, biscuits, wafers, packaged snacks, and sausages. For drinks, the 5 most preferred types are ice cream, bottled water, bottled tea, carbonated drinks, and unpackaged fruit juice/drink. ${ }^{9}$

The small number of children who bring their own homemade meals to school indicates that they need snacks at school as breakfast substitute in order to be able to meet $20 \%$ of their total daily calorie needs $(300 \mathrm{kcal})$. Schools need to provide or sell food with balanced nutrition that can fulfill the calorie needs. Some good examples would be fried/uduk/turmeric rice with side dishes like eggs, fried chicken/nuggets, sausages, sauteed tempeh, sauteed anchovies and peanuts, as well as urap veggies/sauteed kangkung/sauteed carrot and green beans, or fried noodle/vermicelli with side dishes of eggs/nuggets/sausages and vegetables. Examples of snacks are rice cake/rice/pastry/rissoles/fried bread filled with minced vegetable (carrots, beans, etc.), milk and fruit egg pudding, mambo ice with fruit or milk and mung beans, fruit soup with milk and mung beans/chocolate sprinkles/kidney beans topping, or fresh fruit juice with milk and no sugar.

Based on the observation in some schools, school cafeterias and hawkers outside the school sell similar types of food: unhealthy snacks with questionable hygiene that contain food additives (dyes, preservatives, seasoning, etc.). As a result, those food only fulfill the calorie needs but lacking in nutrients, thereby negatively impacting the health and nutritional status of school children. The existence of school cafeteria is expected to help addressing this problem by exclusively providing affordable, healthy and nutritious snacks that the children would like. Healthy means free from various biological contamination (germs and dust) and chemical contamination (food additives), ${ }^{27}$ as well as nutritious as it is made from food ingredients that contain complete nutrients required by schoolage children. The cafeteria manager can also educate schoolchildren on how to select healthy and nutritious snacks, so they will gradually prefer to buy snacks only from the school cafeteria/canteen.

\section{Conclusion}

Primary school-aged children in Indonesia are experiencing triple burden of malnutrition, with undernutrition, overnutrition and micronutrient deficiency. Such problems are due to their lack of appropriate nutritional intakes, parents' poor knowledge on children nutritional needs, absence of breakfast, as well as the availability of unhealthy food and snacks sold at school. Therefore, there is an urgent need to immediately continue the nutritional improvement program in schools that are more practical, independent, and sustainable in order to support the foundation of Sekolah Generasi Maju in Indonesia. Recommended activities would be introducing healthy and nutritious ingredients to make snacks sold in the school cafeteria that schoolchildren will like, as well as nutrition education activities for school children and cafeteria/canteen managers. 
Table 1. Recommended dietary intakes for school-age children

\begin{tabular}{|c|c|c|c|c|c|c|c|c|c|c|c|c|c|c|}
\hline \multirow{2}{*}{$\begin{array}{l}\text { Age } \\
\text { Group } \\
\text { (year) }\end{array}$} & \multirow{2}{*}{$\begin{array}{l}\text { Energy } \\
\text { (kcal) }\end{array}$} & \multirow{2}{*}{$\begin{array}{l}\text { Protein } \\
\text { (g) }\end{array}$} & \multirow{2}{*}{$\begin{array}{l}\text { Total } \\
\text { Fat } \\
\text { (g) }\end{array}$} & \multicolumn{2}{|c|}{ Unsaturated fat (g) } & \multirow{2}{*}{$\begin{array}{l}\text { Carbohydrat } \\
\text { es } \\
\text { (g) }\end{array}$} & \multirow{2}{*}{$\begin{array}{l}\text { Calcium } \\
\text { (mg) }\end{array}$} & \multirow{2}{*}{$\begin{array}{l}\text { Iron } \\
\text { (mg) }\end{array}$} & \multirow{2}{*}{$\begin{array}{l}\text { Zinc } \\
\text { (mg) }\end{array}$} & \multirow{2}{*}{$\begin{array}{l}\text { Iodine } \\
\text { (mcg) }\end{array}$} & \multirow{2}{*}{$\begin{array}{l}\text { Fiber } \\
\text { (g) }\end{array}$} & \multirow{2}{*}{$\begin{array}{l}\text { Vit A } \\
\text { (mcg) }\end{array}$} & \multirow{2}{*}{$\begin{array}{l}\text { Vit } \\
\text { C } \\
\text { (mg) }\end{array}$} & \multirow{2}{*}{$\begin{array}{l}\text { Vit D } \\
\text { (mcg) }\end{array}$} \\
\hline & & & & Omega 3 & Omega 6 & & & & & & & & & \\
\hline $7-9$ & 1650 & 40 & 55 & 0.9 & 10 & 250 & 1000 & 10 & 5 & 120 & 23 & 500 & 45 & 15 \\
\hline \multicolumn{15}{|l|}{ Male } \\
\hline $10-12$ & 2000 & 50 & 65 & 1.2 & 12 & 200 & 1200 & 8 & 8 & 120 & 28 & 600 & 50 & 15 \\
\hline \multicolumn{15}{|l|}{ Female } \\
\hline $10-12$ & 1900 & 55 & 65 & 1.0 & 10 & 280 & 1200 & 8 & 8 & 120 & 27 & 600 & 50 & 15 \\
\hline
\end{tabular}

Source: Regulation of Minister of Health of the Republic of Indonesia (Permenkes RI) No. 28 of 2019 on the Recommended Dietary Allowances (AKG) recommended for the people of Indonesia ${ }^{28}$

Table 2. Iron and zinc content in food ingredients

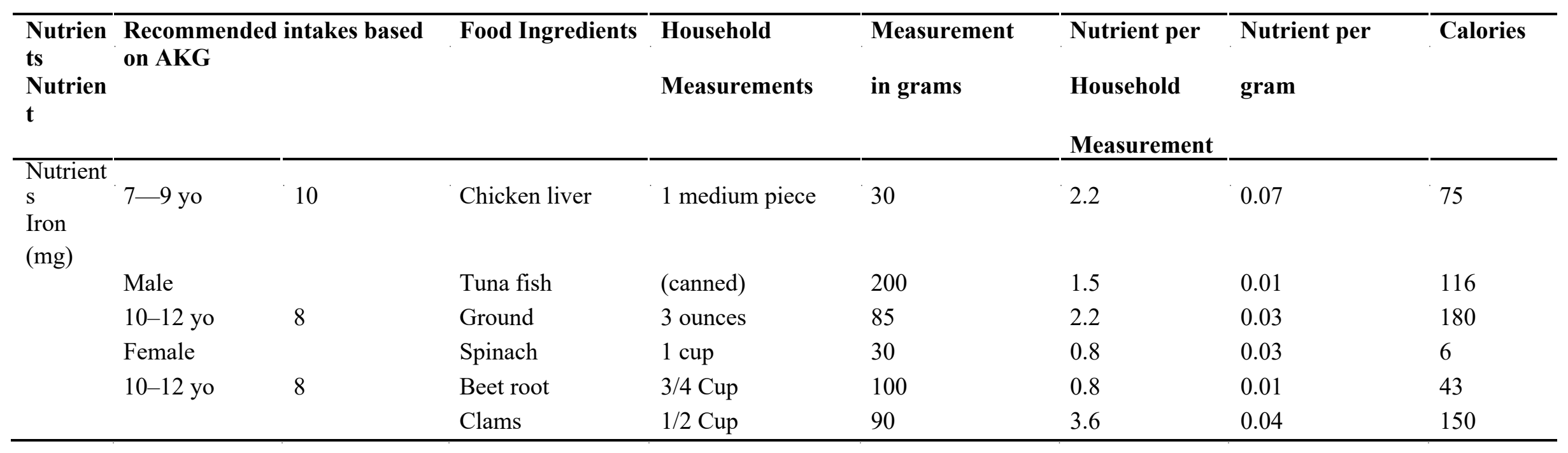




\begin{tabular}{|c|c|c|c|c|c|c|c|}
\hline \multirow[t]{10}{*}{$\begin{array}{l}\text { Nutrien } \\
\text { ts } \\
\text { Nutrien } \\
\text { t }\end{array}$} & $\begin{array}{l}\text { Recommended intakes based } \\
\text { on AKG }\end{array}$ & Food Ingredients & $\begin{array}{l}\text { Household } \\
\text { Measurements }\end{array}$ & $\begin{array}{l}\text { Measurement } \\
\text { in grams }\end{array}$ & $\begin{array}{l}\text { Nutrient per } \\
\text { Household } \\
\text { Measurement }\end{array}$ & $\begin{array}{l}\text { Nutrient per } \\
\text { gram }\end{array}$ & Calories \\
\hline & & Mackerel & 1 whole piece & 90 & 0.9 & 0.01 & 150 \\
\hline & & Shrimp & 5 medium shrimps & 35 & 0.9 & 0.03 & 50 \\
\hline & & Mackerel Tuna & 1 ounce & 100 & 0.7 & 0.01 & 30 \\
\hline & & Kidney Beans & 2 tablespoons & 20 & 1.5 & 0.08 & 75 \\
\hline & & Kangkung & 1 ounce & 100 & 1.1 & 0.01 & 25 \\
\hline & & Long beans & 1 ounce & 100 & 1.3 & 0.01 & 25 \\
\hline & & Red spinach & 1 ounce & 100 & 3.1 & 0.03 & 50 \\
\hline & & Katuk leaf & 1 ounce & 100 & 2.3 & 0.02 & 50 \\
\hline & & Snow peas & 1 ounce & 100 & 1.5 & 0.02 & 50 \\
\hline \multirow{9}{*}{$\begin{array}{l}\text { Zinc } \\
\text { (Zinc, } \\
\text { mg) }\end{array}$} & $7-9$ yo & Oyster & 1 whole piece & 28 & 12.8 & 0.46 & 30 \\
\hline & Male & Clams & 1/2 Cup & 90 & 1.4 & 0.02 & 50 \\
\hline & $10-12$ уо & Crab & 1 medium chicken & 30 & 3.8 & 0.13 & 50 \\
\hline & Female & Shrimp & 5 medium shrimps & 30 & 1.8 & 0.06 & 50 \\
\hline & $10-12$ уо & $\begin{array}{l}\text { Skinless } \\
\text { chicken }\end{array}$ & 1 medium chicken & 40 & 2.4 & 0.06 & 50 \\
\hline & & $\begin{array}{l}\text { Ground } \\
\text { beef }\end{array}$ & 3 ounces & 30 & 3.8 & 0.13 & 75 \\
\hline & & Kidney Beans & 2 tablespoons & 20 & 0.6 & 0.03 & 75 \\
\hline & & Katuk leaf & 1 ounces & 100 & 0.5 & 0.01 & 50 \\
\hline & & Snow peas & 1 ounces & 100 & 1.2 & 0.01 & 50 \\
\hline
\end{tabular}




\section{Conflict of Interest}

Authors declared no conflict of interest regarding 9. this article.

\section{Acknowledgment}

We would like to thank PT Sarihusada Generasi Mahardhika for helping us translating this article.

\section{Open Access}

This article is distributed under the terms of the Creative Commons Attribution 4.0 International 13. Licence

(http://creativecommons.org/licenses/by/4.0/), which permits unrestricted use, distribution, and reproduction in any medium, provided you give appropriate credit to the original author(s) and the 14 . source, provide a link to the Creative Commons license, and indicate if changes were made.

\section{References}

1. FAO regional office for Europe and Central Asia. The 16 triple burden of malnutrition in Europe and Central Asia: a multivariate analysis.

2. Badan Penelitian dan Pengembangan Kesehatan. Riset Kesehatan Dasar 2013. Kementerian Kesehatan Republik Indonesia; 2013.

3. Kemenkes RI. Laporan Provinsi Jawa Barat 17. RISKESDAS 2018. 2019.

4. Phrashiah G, Peter C, Scolastica G. Nutritional status and school performance among upper primary children in selected public schools in Nairobi County, Kenya. Int J Health Sci Res. 2016;6(12):227-34.

5. Yadika A, Berawi K, Nasution S. Pengaruh stunting 18. terhadap perkembangan kognitif dan prestasi belajar. Medical Journal of Lampung University. 2019;8(2):273-82.

6. Emerson E, Savage A, Llewellyn G. Prevalence of underweight, wasting and stunting among young 19. children with a significant cognitive delay in 47 lowincome and middle-income countries. Journal of Intellectual Disability Research. 2020 Feb;64(2):93- 20. 102.

7. Woldehanna T, Behrman JR, Araya MW. The effect of early childhood stunting on children's cognitive 21 . achievements: Evidence from young lives Ethiopia. Ethiop J Health Dev. 2017;31(2):75-84.

8. Anzarkusumah I, Mulyani E, Jus'at I, Angkasa D. 22. Status gizi berdasarkan pola makan anak sekolah dasar di Kecamatan Rajeg, Tangerang (Nutritional status based on primary school student's dietary intake in
Rajeg district, Tangerang City). IJHN. 2014;1(2):13548.

Marhamah, Abzeni, Juwita. Perilaku konsumsi dan status gizi anak sekolah dasar di kota Serang. Jurnal Matematika Sains dan Teknologi. 2014;15(2).

Rahmawati T, Marfuah D. Gambaran status gizi pada anak sekolah dasar. Profesi. 2016 Sep 1;14(1):72.

11. Yurni A, Sinaga T. Pengaruh pendidikan gizi terhadap pengetahuan dan praktik membawa bekal menu seimbang anak sekolah dasar. Media Gizi Indonesia. 2017;12(2):183-90.

Sekiyama M, Roosita K, Ohtsuka R. Locally Sustainable School Lunch Intervention Improves Hemoglobin and Hematocrit Levels and Body Mass Index among Elementary Schoolchildren in Rural West Java, Indonesia. Nutrients. 2017;9(8):868.

Syahrul S, Kimura R, Tsuda A, Susanto T, Saito R, Ahmad F. Prevalence of underweight and overweight among school-aged children and it's association with children's sociodemographic and lifestyle in Indonesia. International Journal of Nursing Sciences. 2016 Jun;3(2):169-77.

Jahri I, Suyanto, Ernalia Y. Gambaran status gizi pada siswa sekolah dasar kecamatan Siak Kecil, Kabupaten Bengkalis [Disertation]. Riau University; 2016.

15. Yulia C, Khomsan A, Sukandar D, Riyadi H. Studi cross-sectional: gambaran perilaku gizi anak usia sekolah dasar di kota Bandung. Media Pendidikan Gizi dan Kuliner. 2018;7(1):9-17.

Riana A, Kristiandi K, Musa E, Malaihollo AA, Saragih B, Simamora D. Hubungan status gizi dan perilaku gizi pada siswi di MI Al-Ishlah Bandung. gemassika [Internet]. 2018 May 30 [cited 2021 Feb 8];2(1). Available from: http://jurnal.stikesaisyiyah.ac.id/index.php/gemassika/article/view/273

Bardosono S, Dewi LE, Sukmaniah S, Permadhi I, Eka $\mathrm{AD}$, Lestarina L. Effect of a six-month iron-zinc fortified milk supplementation on nutritional status, physical capacity and speed learning process in Indonesian underweight schoolchildren: randomized, placebo-controlled. Med J Indones. 2009 Aug 1;193.

Sandjaja S, Budiman B, Harahap H, Ernawati F, Soekatri M, Widodo Y, et al. Food consumption and nutritional and biochemical status of 0.5-12-year-old Indonesian children: the SEANUTS study. Br J Nutr. 2013 Sep;110(S3):S11-20.

Wooldridge N. Child and preadolescent nutrition. In: Nutrition Through the Life Cycle. 4th ed. Wadsworth/Cengage Learning; 2011.

Gallagher M. The nutrients and their metabolism. In: Krause's Food and Nutrition Therapy. 13th ed. Missouri: Saunders Elsevier; 2012. p. 52-3.

Gropper SAS. Advanced nutrition and human metabolism. 6th ed. Wadsworth/Cengage Learning; 2013.

Falkingham M, Abdelhamid A, Curtis P, FairweatherTait S, Dye L, Hooper L. The effects of oral iron supplementation on cognition in older children and 
adults: a systematic review and meta-analysis. Nutrition Journal. 2010;9(1):1-6.

23. Badan Litbangkes, Kemenkes RI. Riset Kesehatan Dasar (Riskesdas) tahun 2010 [Internet]. 2010. Available from: https://www.kemkes.go.id/resources/download/infoterkini/hasil-riskesdas-2018.pdf

24. Wolde M, Berhan Y, Chala A. Determinants of underweight, stunting and wasting among schoolchildren. BMC Public Health. 2015 Dec;15(1):8.

25. Nuryani N, Rahmawati R. Kebiasaan jajan berhubungan dengan status gizi siswa anak sekolah di Kabupaten Gorontalo. JGI. 2018 Aug 1;6(2):114-22.

26. Hardinsyah $\mathrm{H}$, Aries $\mathrm{M}$. Jenis pangan sarapan dan perannya dalam asupan gizi harian anak usia 6-12 tahun di Indonesia. J Gizi Pangan. 2016 Jun 21;7(2):89.

27. Direktorat Standardisasi Produk Pangan. Pedoman pangan jajanan anak sekolah untuk pencapaian gizi seimbang. 2013. 3-4 p.

28. PERMENKES. Peraturan menteri kesehatan Republik Indonesia No. 28 tahun 2019 tentang Angka Kecukupan Gizi yang dianjurkan untuk masyarakat Indonesia. 2019;

29. Waspadji S, Sukardji K, Suharyati. Menyusun diet berbagai penyakit. 4th ed. Jakarta, Indonesia: Badan Penerbit FKUI; 2013.

30. Erhardt J. Nutrisurvey for Windows. Universitas Indonesia: SEAMEO-TROPMED; 2005. 